\title{
Study on the Effect of Apelin or Angiotensin-1 Receptor Blocker on Atherosclerotic Model
}

\author{
Maessa M. El-Nahas*, Fleur F. Ibrahim**, Waffa M. Ibrahim*** \\ Department of Physiology*, Pharmacology** and Biochemistry*** \\ Faculty of Medicine Tanta University
}

\begin{abstract}
The aim of this study was to investigate the effect of apelin (one of adipokine) or losartan (angiotensin-1 receptor blocker) on atherosclerotic and inflammatory markers in hypercholesterelemic rats treated with angiotensin II injection. Forty male albino rats divided into two groups Control $n=8$ and high cholesterol diet group $n=$ 32 which were further subdivided into 4 subgroups. Saline, AngII, AngII + losartan and AngII + apelin for 4 weeks. At the end of experiments their plasma were used and analyzed for lipid profiles, TNF-alpha, NO, CRP and SVCAM-1 where they showed significant increase in lipid profiles in saline and Ang II group and significant decrease after losartan or apelin treatment. TNF-alpha., CRP and SVCAM-1 were significantly increased after saline and Ang II, while decreased significantly after losartan or apelin. The level of NO was significantly decreased in saline and Ang II group and significantly increased after losartan or apelin. The present study indicates that apelin exerts an antiatherogenic effect and counteracts the effect of Ang II like losartan via inhibiting the atherogenic and inflammatory markers in hypercholesterelemic rats.
\end{abstract}

\section{INTRODUCTION}

The endothelium plays a central role in the maintenance of vascular homeostasis. One of the main effectors of endothelial dysfunction is angiotensin II (Ang II) and pharmacological approaches to limit AngII bioactivity remain the corner stone of cardiovascular therapeutics ${ }^{(1)}$. AngII promotes generation of oxidative stress in the vasculature which appears to be a key mediator of AngII induced endothelial dysfunction, endothelial cell apoptosis and lipoprotein peroxidation ${ }^{(2)}$.

Losartan is a specific angiotensin1 receptor (AT-1) antagonist which can effectively inhibit the effect of AngII. However, the effect of losartan on atherosclerosis has been rarely demonstrated ${ }^{(3)}$.

Adipocytokines secreted by adipose tissue have an important role in inflammation which is considered to be a crucial pathogenic factor of atherosclerosis ${ }^{(4)}$. Apelin a relatively newer adipokine with various actions on cardiovascular system causing dyslipidemia ${ }^{(5)}$.

Apelin is expressed primarily in the endothelium and act both locally and via endocrine signaling to activate cognate G protein coupled receptor (orphan receptor APJ), which is expressed on myocardial cells, endothelial cells and some smooth 
muscle cells ${ }^{(6)}$. Apelin has been shown to have a positive effect on contractility and in the vasculature. ${ }^{(7)}$ Other studies support a vasodepressor role in both the arterial and venous circulation and supposed that these effects are mediated at least in part by nitric oxide ${ }^{(\mathbf{8})}$. These data suggest that the vascular action of apelin may be complex and involve effects in addition to eNOS activation depending on the apelin dose, species and other experimental factors. Apelin is identified as AngII homologue which counteracts the actions of AngII. In addition, there is a sequence homology between apelin and AT1 receptors and the anatomical distribution of both receptors and peptides overlap in the cardiovascular system $^{(\mathbf{9})}$. However, the functional effects of apelin are independent of AT1 receptor and APJ receptors do not show specific binding of AngII ${ }^{(\mathbf{1 0})}$.

The aim of the present work is to study the effect of losartan as an AT-1 receptor blocker or apelin and its APJ system on atherosclerosis produced by high cholesterol diet and treated by injection of AngII in rats.

\section{MATERIAL \& METHODS}

This study was carried out on forty male albino rat, collected randomly weighing $205 \pm 18 \mathrm{~g}$ body weight. These animals were housed under 12 hours day/night cycle at room temperature.

They are classified into 2 groups:

1- Control group (8 rats): fed a standard chow and tap water ad libitum.
2- Cholesterol rich diet group (32 rats): fed $2 \%$ cholesterol enriched diet for 8 weeks ${ }^{(11)}$.

These animals are furtherely classified into 4 subgroups: each of 8 rats:

a. Subgroup I: given saline a vehicle subcutaneous.

b. Subgroup II: subcutaneously injected with $\mathrm{Val}^{5}$ Ang II acetate 95\% powder (Sigma Eldritch) in a dose of 7.5 microgram $\backslash \mathrm{kg}$ body weight for 4 weeks $^{(12)}$. (used as atherosclerotic model).

c. Subgroup III: treated by both $\mathrm{Val}^{5}$ AngII S.C. and Losartan (AT-1 receptor blocker) provided as tablets each contain $50 \mathrm{mg}$ by (Amriya Pharma Ind. Egypt) dissolved in saline in a dose of $10 \mathrm{mg} / \mathrm{Kg} /$ day was given by orogastric tube for 4 weeks ${ }^{(13)}$.

d. Subgroup IV: treated by $\mathrm{Val}^{5}$ S.C.and apelin 13 from Sigma was dissolved in saline and given subcutaneously in a dose of $10 \mathrm{nmol} / \mathrm{Kg}$ body weight/day (15.5 microgram $\backslash \mathrm{Kg}$ body weight) for 4 weeks ${ }^{(14)}$.

At the end of the experiments all animals were deprived of food overnight, sacrified in the morning, blood was collected into EDTA coated tubes and plasma was separated and stored until analysis for: 1. Plasma total cholesterol (total $\mathrm{Ch}$ ) determined by methods of Allain et al., ${ }^{(15)}$.

2. Plasma low density lipoprotein cholesterol (LDL-C) was determined by method of Fruchart $^{(16)}$.

3. Plasma high density lipoprotein cholesterol (HDL-C) according to the method described by Burstein et al. ${ }^{(17)}$. 
4. Plasma triglycerides (TG) using the methods of Fossati, ${ }^{(\mathbf{1 8})}$.

5. Plasma tumor necrotic factor alpha TNF-alpha was estimated by Commercial Sandwich ELISA kits for rats according to manufacturer's instructions (Biosource, International, Camarillo, California, USA).

6. Nitrite and nitrate (marker to NO level) according to the mehtod of Bartholomew ${ }^{(19)}$.

7. C-reactive protein by Kushner and Sommerville ${ }^{(\mathbf{2 0})}$.

8. Soluble vascular cell adhesion molecule (SVCAM-1) are measured by immunosorbent assay (ELISA) using commercially available kits $^{(21)}$.

\section{Statistical analysis:}

Data were presented as a mean value $\pm \mathrm{SD}$ and analysis of the results using one way ANOVA differences between individual groups were determined with the Scheffe test. Results were considered significant at $\mathrm{P}<0.05$ using SPSS computer program version 16.

\section{RESULTS}

Table (1) shows that total cholesterol, LDL-C and TG are significantly increased after high cholesterol diet while HDLcholesterol was significantly decreased. After AngII injection total cholesterol, LDL-C and triglycerides are significantly increased in comparison to high cholesterol diet while HDL cholesterol decreased significantly $\mathrm{P}<0.05$. After giving losartan orally or apelin subcutaneously total cholesterol, LDL-C and TG showed significant decrease in comparison to AngII group alone $\mathrm{P}<0.05$. While $\mathrm{HDL}$ significantly increased $\mathrm{P}<0.05$ Fig. (1).

Tumor necrotic factor alpha is significantly increased after high cholesterol diet alone or together with AngII , while treatment with losartan or apelin with AngII showed significant decrease $\mathrm{P}<0.05$ table \& Fig. (2).

Also, as shown in table (2) there is a significant decrease in NO after saline or AngII in high cholesterol diet fed rats as compared to normal fed group $\mathrm{P}<0.05$ and it increased significantly after losartan or apelin treatment Fig (3).

Concerning C-reactive protein it is significantly increased after saline and AngII injection but significantly decreased after treatment with losartan or apelin Fig. (4)

SVCAM-1 is significantly increased in saline and AngII group and significantly decreased after treatment with losartan or apelin $\mathrm{P}<0.05$ table (2) \& fig (5). 
Table (1): Plasma level of lipid profiles in studied groups

\begin{tabular}{|c|c|c|c|c|c|c|c|}
\hline & Control & Saline & AngII & $\begin{array}{c}\text { Los } \\
+ \text { AngII }\end{array}$ & $\begin{array}{l}\text { Apelin } \\
+ \text { AngII }\end{array}$ & $\mathbf{F}$ & Relation \\
\hline $\begin{array}{c}\text { Total Ch } \\
\text { mg/dl }\end{array}$ & $\begin{array}{l}98.3 \\
\pm 4.2\end{array}$ & $\begin{array}{l}177.8 \\
\pm 8.3\end{array}$ & $\begin{array}{l}196.2 \\
\pm 14.8\end{array}$ & $\begin{array}{l}188.7 \\
\pm 9.9\end{array}$ & $\begin{array}{l}120.3 \\
\pm 35.1\end{array}$ & $16.3^{*}$ & $\begin{array}{c}\text { (control }<\text { saline }< \\
\text { AngII }>\text { losartan }>\text { apelin }\end{array}$ \\
\hline $\begin{array}{c}\text { LDL-C } \\
\mathrm{mg} / \mathrm{dl}\end{array}$ & $\begin{array}{l}45.3 \\
\pm 7.9 \\
\end{array}$ & $\begin{array}{l}62.1 \\
\pm 3.7 \\
\end{array}$ & $\begin{array}{l}89.2 \\
\pm 4.9\end{array}$ & $\begin{array}{c}79.4 \\
\pm 2.82 \\
\end{array}$ & $\begin{aligned} & 54 \\
& \pm 2.11 \\
&\end{aligned}$ & 9.96* & $\begin{array}{c}\quad \text { control }<\text { saline }< \\
\text { AngII }>\text { losartan }>\text { apelin }\end{array}$ \\
\hline $\begin{array}{c}\text { HDL-C } \\
\mathrm{mg} / \mathrm{dl}\end{array}$ & $\begin{array}{c}24.8 \\
\pm 0.68\end{array}$ & $\begin{array}{l}19.4 \\
\pm 1.6\end{array}$ & $\begin{array}{c}14.4 \\
\pm 2.29\end{array}$ & $\begin{array}{l}18.2 \\
\pm 2.5\end{array}$ & $\begin{array}{c}25.1 \\
\pm 2.75\end{array}$ & $5.36 *$ & $\begin{array}{c}(\text { control }>\text { saline }> \\
\text { AngII }<\text { losartan }<\text { apelin }\end{array}$ \\
\hline TG mg/dl & $\begin{array}{l}123.6 \\
\pm 5.4 \\
\end{array}$ & $\begin{array}{l}163.8 \\
\pm 7.9 \\
\end{array}$ & $\begin{array}{l}187.9 \\
\pm 5.55\end{array}$ & $\begin{array}{l}182.9 \\
\pm 9.1\end{array}$ & $\begin{array}{c}113.05 \\
\pm 8.9\end{array}$ & 37.93* & $\begin{array}{c}\quad \text { control }<\text { saline }< \\
\text { AngII }>\text { losartan }>\text { apelin }\end{array}$ \\
\hline
\end{tabular}

*Significant $\mathrm{P}<0.05$

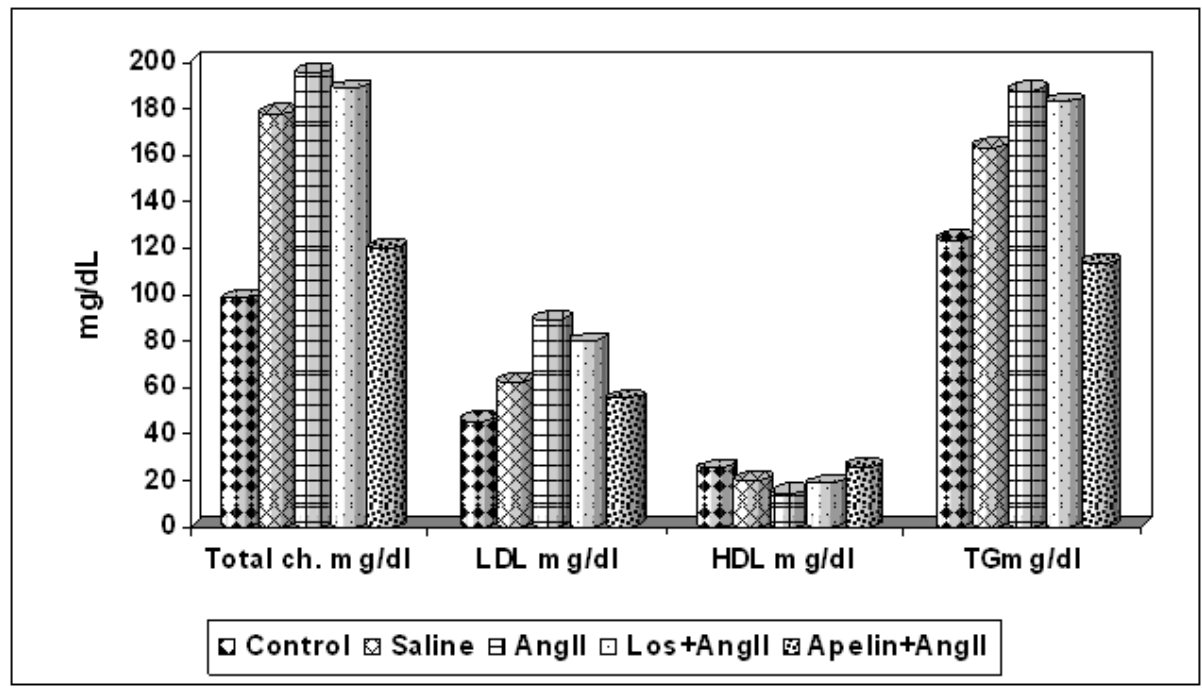

Fig. (1): Plasma level of lipid profiles in studied groups 
Table (2): Plasma level of atherosclerotic and inflammatory markers in studied groups

\begin{tabular}{|c|c|c|c|c|c|c|c|}
\hline & Control & Saline & AngII & $\begin{array}{c}\text { Los } \\
+ \text { AngII }\end{array}$ & $\begin{array}{l}\text { Apelin } \\
+ \text { AngII }\end{array}$ & $\mathbf{F}$ & Relation \\
\hline $\begin{array}{l}\text { TNF- } \alpha \\
\text { pg/ml }\end{array}$ & $\begin{array}{r}20.3 \\
\pm 3.3 \\
\end{array}$ & $\begin{array}{l}49.56 \\
\pm 3.4\end{array}$ & $\begin{array}{l}59.17 \\
\pm 5.9\end{array}$ & $\begin{array}{l}46.42 \\
\pm 4.5\end{array}$ & $\begin{array}{l}39.11 \\
\pm 3.81\end{array}$ & $16.61 \%$ & $\begin{array}{c}(\text { control }<\text { saline }< \\
\text { AngII }>\text { losartan }>\text { apelin })\end{array}$ \\
\hline $\begin{array}{l}\text { Nitrite/nitr } \\
\text { ate } \mathrm{nmol} / \mathrm{ml}\end{array}$ & $\begin{array}{c}24.9 \\
\pm 2.01 \\
\end{array}$ & $\begin{array}{l}14.9 \\
\pm 2.3 \\
\end{array}$ & $\begin{array}{c}9.34 \\
\pm 3.46\end{array}$ & $\begin{array}{c}23.5 \\
\pm 1.13 \\
\end{array}$ & $\begin{array}{l}24.3 \\
\pm 2.7 \\
\end{array}$ & 19.23* & $\begin{array}{c}\text { (control }<\text { saline }< \\
\text { AngII }>\text { losartan }>\text { apelin }\end{array}$ \\
\hline CRP mg/l & $\begin{array}{c}5.3 \\
\pm 0.96\end{array}$ & $\begin{array}{c}6.6 \\
\pm 2.99\end{array}$ & $\begin{array}{c}8.4 \\
\pm 2.13\end{array}$ & $\begin{array}{c}6.2 \\
\pm 2.75\end{array}$ & $\begin{array}{c}5.4 \\
\pm 0.32\end{array}$ & 7.263 & $\begin{array}{c}\text { (control }<\text { saline }< \\
\text { AngII }>\text { losartan }>\text { apelin }\end{array}$ \\
\hline $\begin{array}{c}\text { SVCAM-1 } \\
\text { ng/ml }\end{array}$ & $\begin{array}{c}25.1 \\
\pm 4.32\end{array}$ & $\begin{array}{c}33.3 \\
\pm 6.29\end{array}$ & $\begin{array}{c}48.7 \\
\pm 8.71\end{array}$ & $\begin{array}{c}37.5 \\
\pm 3.25\end{array}$ & $\begin{array}{c}31.2 \\
\pm 6.90\end{array}$ & 12.253 & $\begin{array}{c}\text { (control }<\text { saline }< \\
\text { AngII }>\text { losartan }>\text { apelin }\end{array}$ \\
\hline
\end{tabular}

*Significant $P<0.05$

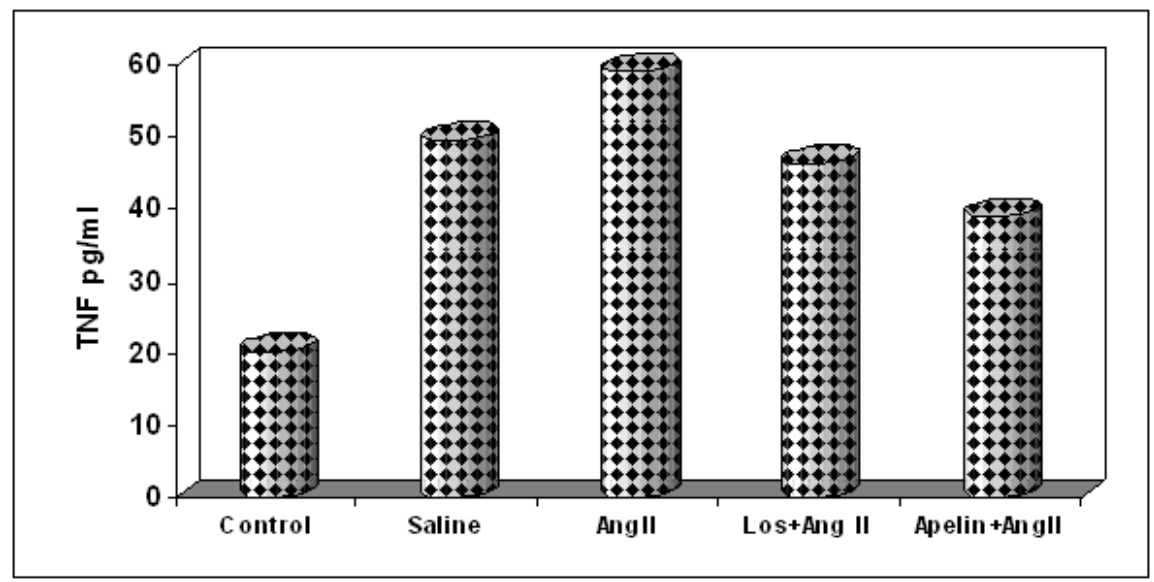

Fig. (2): Plasma level of tumor necrotic factor $\alpha$ in studied groups

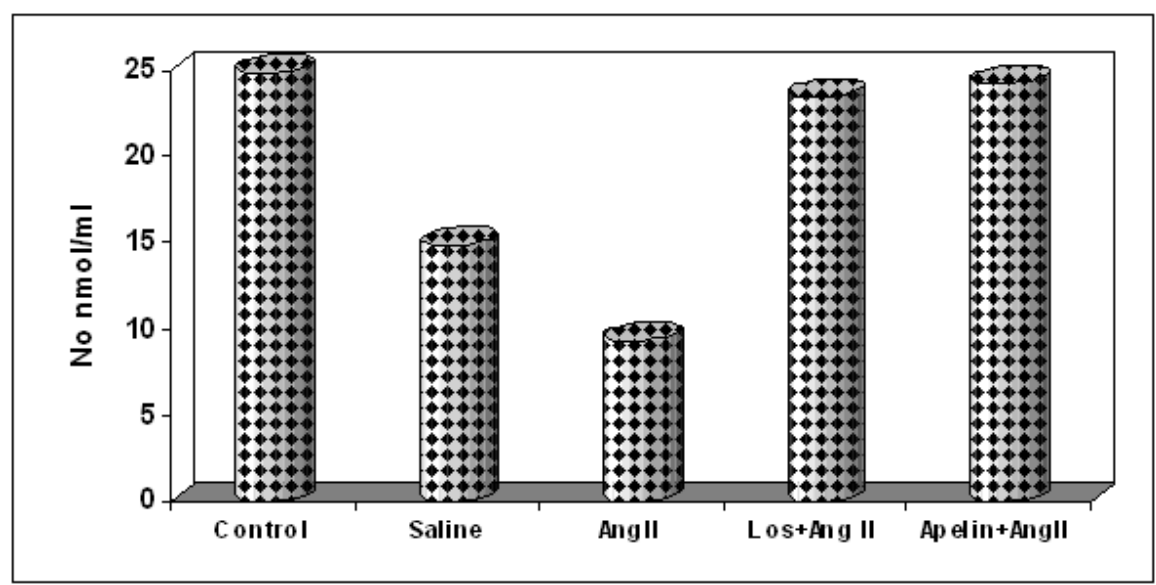

Fig. (3): Plasma level of nitric oxide in studied groups 


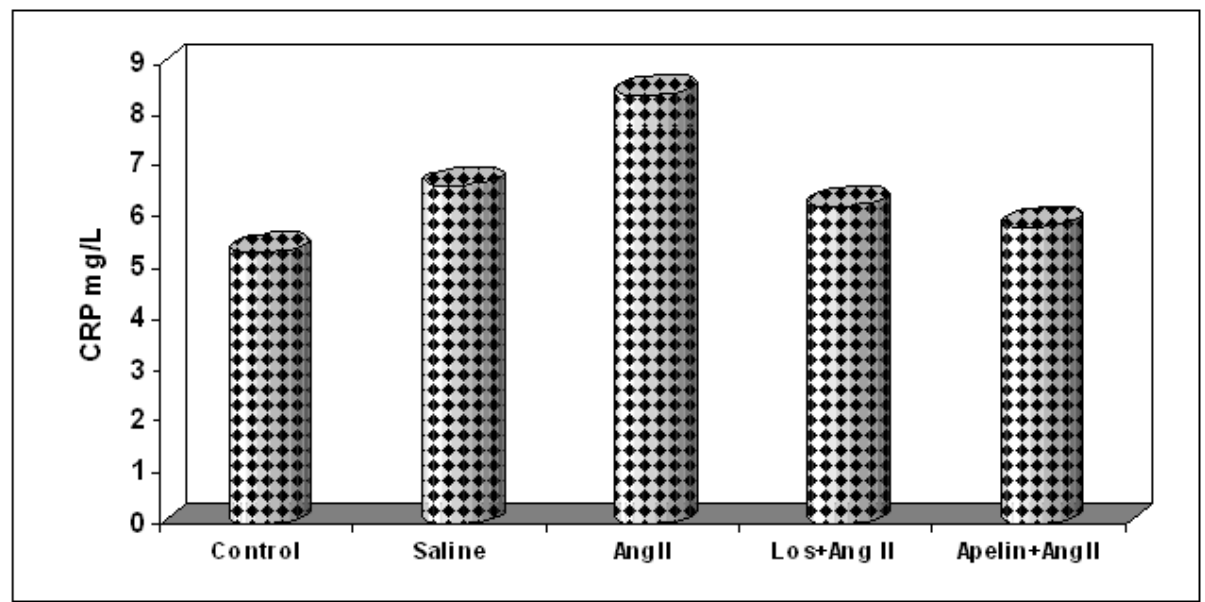

Fig. (4): Plasma level of C - reactive protein in studied groups

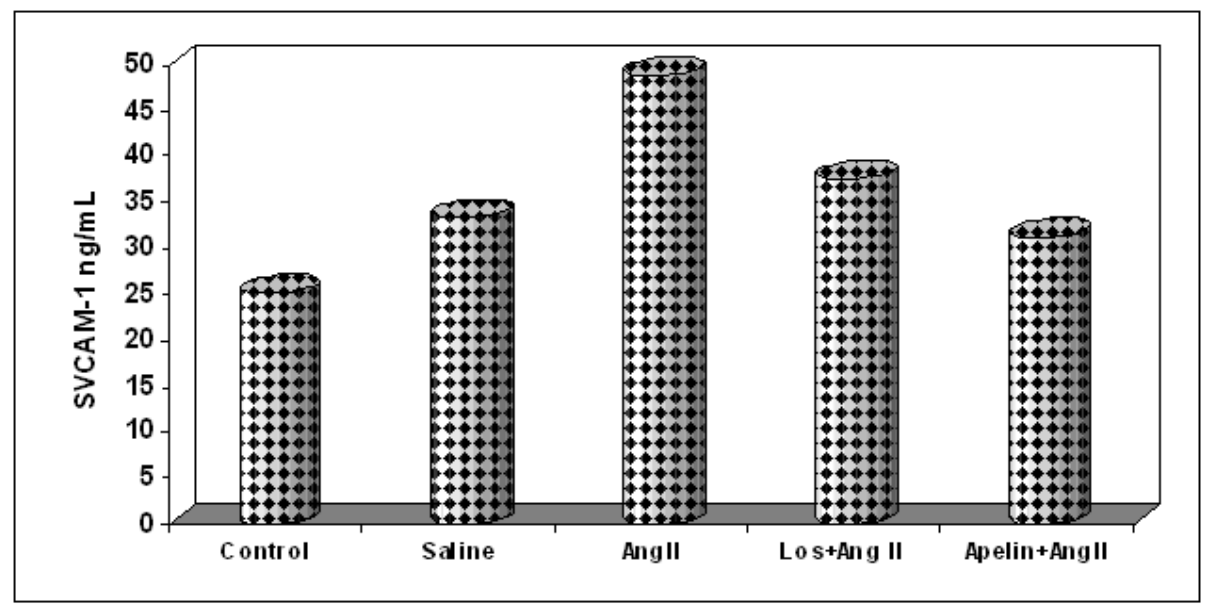

Fig. (5): Plasma level of vascular cell adhesion molecule in studied groups 


\section{DISCUSSION}

In the fact of existing data suggesting a prominent role of AngII in mediating atherosclerosis in hypercholesterolemic rats since it promotes generation of oxidative stress in the vasculature, which appears to be a key mediator of AngII induced endothelial dysfunction ${ }^{(2)}$. AngII exerts direct effects on the arterial wall to influence atherosclerosis with the induction of vascular inflammation ${ }^{(22)}$. AngII is known to accelerate the progression of macrophage-driven atherosclerotic lesions. Acyl-CoA cholesterol acyletransferase-1 converts intracellular free cholesterol into cholesterol ester for storage in lipid droplets and promotes foam cell formation in atherosclerotic lesions ${ }^{(23)}$.

The mechanism of increased production of reactive oxygen species (ROS) by angiotensin II may serve as a causal link between hypercholesterolemia and many of the major pathways responsible for atherogenic disorders ${ }^{(24)}$.

Endothelial dysfunction in this work may be due to impaired nitric oxide (NO) synthesis and/or inactivation of endothelium derived NO by ROS. Endothelial dysfunction complicates hypertension and is a precursor of atherosclerosis characterized by reduction in bioavailability of vasodilators particularly nitric oxide and an increase in the activity of vasoconstrictors including AngII and reactive oxygen species (ROS). Nitric oxide antagonizes the vasoconstrictive and pro-atherosclerotic effects of
AngII whereas AngII decrease nitric oxide bioavailability by promoting oxidative stress $^{(25)}$.

The present study showed that TNF-alpha significantly increased after hypercholesterolemia and AngII injection. AngII stimulates NF-kappa $\mathrm{B}$ nuclear translocation in vascular smooth muscle cells (VSMC) via AT1 receptors as TNF-Alpha in particular promotes the expression of cell adhesion molecules by endothelial cells ${ }^{\mathbf{( 2 6 )}}$. Furthermore increased plasma levels of soluble cell adhesion molecules have been found in inflammation $^{(27)}$. AngiotensinII contributes to atherosclerosis at both transcriptional and transitional levels by up regulating adhesion molecule mRNA and protein synthesis ${ }^{(25)}$.

Nuclear factor kappa B activation is related to AT-1 receptor mediated pathways activation of the rennin angiotensin system is a mechanism for the initiation and progression of inflammatory cell infiltration found in early changes common to hypercholesterolemia $^{(25)}$. So, we suggested that vascular dysfunction observed in this work could be due to inflammation.

The recruitment of monocytes via the endothelial expression of vascular cell adhesion molecule-1 (VCMA-1) is a key step in the formation of the initial lesion in atherosclerosis ${ }^{(\mathbf{2 8})}$.

One accepted mechanism for many of the actions of AngII in vascular wall disease is its effect on the balance of reactive oxygen species. The related decrease in NO availability and the inflammatory consequences in vascular wall cells 
are thought to be intimately involved in the disease process ${ }^{(29)}$.

AngII stimulates mRNA and protein expression of VCAM-1 via the AT1 receptor. This effect was enhanced by $\mathrm{N}$ (G)-nitro-L0arginine methyl ester, a nitric oxide syntheses inhibitor ${ }^{(30)}$.

In the present work C-reactive protein increased after AngII injection because AngII is capable of inducing C-RP generation in vascular smooth muscle cells in which AngII type -1 receptor followed MAPK signal pathway is involved ${ }^{(31)}$.

As appeared from the present results that losartan an AT-1 receptor blocker significantly decrease the dyslipidemia and inflammatory markers and this agree with Dandona et al., ${ }^{(30)}$ as AngII receptor blocker's suppress mediators of inflammation, included reactive oxygen species and C-reactive protein and increase expression of inhibitory kappa B . These anti-inflammatory and antioxidative effects which are probably due in part to unopposed stimulation of the AngII, type 2 receptors $^{(30)}$.

Losartan reduces LDL cholesterol and atherosclerotic plaque formation in rodent ${ }^{(31)}$. Accumulation and modification of low density lipoproteins (LDL-C) within the vessel wall represent key events in atherogenesis. AT-1 receptor blockade reduces LDL-C modification and atherosclerotic plaque formation in rodents and primate models of atherosclerosis. AT-1 receptor blockade reduces secretory phospholipase A2 type II-A level and activity and subsequently lipid peroxidation. These finding imply that AT-1 receptor blockade elicit anti atherosclerotic potencies even in the absence of plasma cholesterol reduction $^{(32)}$.

Nitric oxide antagonizes the proatherosclerotic effects of AngII, inhibition of AngII type 1 receptor by losartan prevent the development of endothelial dysfunction through stimulation of nitric oxide production $^{(33)}$.

The present study showed that parameters indicating dyslipidemia and atherosclerosis are decreased after apelin injection. Tasci et al. ${ }^{(33)}$ reported that reduction in LDL cholesterol levels in people with dyslipidemia results in an increase in plasma apelin concentration which indicates a role for apelin in the mechanism of atherosclerosis.

Data reported here show that apelin blocks a spectrum of AngII mediated effects on atherosclerosis. These endpoints result from a number of pathophysiological processes that are regulated by AngII in the setting of vascular wall disease including direct effects on cellular adhesion, proliferation, migration hypertrophy and to degradation of matrix proteins and collagen ${ }^{(34)}$.

Iwanaga et al. ${ }^{(35)}$,, reported that in AngII infused rats, apelin mRNA was decreased after $24 \mathrm{~h}$ of treatment and its restoration was achieved by treatment with losartan. Regulation of AngII signaling by the endogenous apelin APJ pathway thus becomes an important variable for consideration.

Jiu-Chang et al. $^{(36)}$ found that there is a reciprocal relationship between the apelin APJ system and the AT1 signaling. Mechanisms that participate in the reduced vasodilator responses in diabetes include 
increased production of AngII, decreased NO generation, oxidative stress and diminished expression of the apelin APJ system. Atherosclerosis is due to inflammatory conditions and Zong et al. ${ }^{(37)}$ found that TNF-alpha produced as inflammatory mediator stimulates endogenous apelin.

Apelin effects on the vascular wall have focused on the endothelium and the eNOS dependent production of NO where apelin potentates phosphorylation of eNOS ${ }^{(37)}$.

One mechanism for apelin mediated amelioration of atherosclerosis might be related to increase NO production and the result of the present study shows that apelin increases production of $\mathrm{NO}$ (table2). Also, in this work blocking AngII signaling by apelin decrease the well characterized proatherosclerotic effects of AngII such as increased adhesion molecule level ${ }^{(38)}$.

Studies on mice revealed that apelin-induced hypotension is abolished by inhibition of nitric oxide syntheses and the angiotensin II hypertensive response is enhanced by APJ deficient animal. These results suggest not only that apelin vasodilatation is mediated by $\mathrm{NO}$, but also that APJ receptors counteract the pressor effect of angiotensin II, possibly in response to a basal level of apelin from the vascular endothelial cells and in spite of a similarity between APJ and angiotensin II type1 receptors ${ }^{(39)}$.

Also Hus-Citharell et al. ${ }^{(\mathbf{4 0})}$ reported that activation of apelin receptors caused release of nitric oxide which inhibited angiotensin II induced rise in intracellular calcium.
Our results agree with Erdem et al. ${ }^{(41)}$ as dysregulation of apelin might be involved in the mechanism of establishment of diabetes associated with atherosclerosis.

There is some evidence for direct counter regulation of the rennin angiotensin system by apelin $\mathrm{APJ}^{(\mathbf{4 2})}$ and it appears from other works that AngII increases vascular tone and raises blood pressure. Apelin is a vasodilator and lower blood pressure AngII and apelin are expressed in functionally apposing neurons in the hypothalamus and AngII promotes vasopressin release while apelin inhibits its release. Also glucocorticoids increase AngII levels and suppress apelin expression ${ }^{(\mathbf{4 3})}$.

\section{Conclusion:}

The present data establish that apelin can block a number of AngII related pathological processes associated with atherosclerosis on effect similar to that of AT-1 blocker (losartan). This inhibitory activity is likely mediated by increased endothelial NO production. These data suggest a role for the apelin APJ pathway in atherosclerosis and AngII mediated vascular remodeling and provide directions for additional studies and further investigations for the mechanisms of the observed effects.

\section{REFERENCES}

1. Lovren F, Pan Y, Quan A, Teoh H, Wang G, Shukla PC, Levitt KS, Oudit GY, Al-Omran M, Stewart DJ, Slutsky AS, Peterson MD, Backx PH, Penninger JM, Verma S. Angiotensin converting enzyme-2 
confers endothelial protection and attenuates atherosclerosis. Am J Physiol Heart Circ Physiol. 2008 Oct; 295(4): H1377-84.

2. Schmidt-Ott KM, Kagiyama S, Phillips MI. The multiple actions of angiotensin II in atherosclerosis. Regul Pept. 2000 Sep 25; 93(1-3):65-77.

3. Xu HX, Li JJ, Li GS, Wang J, Li NX, Peng J. Decreased infiltration of macrophages and inhibited activation of nuclear factor-kappa B in blood vessels: a possible mechanism for the antiatherogenic effects of losartan. Acta Cardiol. 2007 Dec; 62 (6): 607-13.

4. Amasyali B, Kose S, Kursaklioglu H, Barcin C, Kilic A. Monocyte hemoattractant protein-1 in acute coronary syndromes: Complex vicious interaction. Int J Cardiol. 2008 Aug 4.

5. Tasci I, Erdem G, Ozgur G, Tapan S, Dogru T, Genc H, Acikel C, Ozgurtas T, Sonmez A. LDL-cholesterol lowering increases plasma apelin in isolated hypercholesterolemia. Atherosclerosis. 2008; Sep. 4.

6. Sheikh AY, Chun HJ, Glassford AJ, Kundu RK, Kutschka I, Ardigo D, Hendry SL, Wagner RA, Chen MM, Ali ZA, Yue P, Huynh DT, Connolly AJ, Pelletier MP, Tsao PS, Robbins RC, Quertermous T. In vivo genetic profiling and cellular localization of apelin reveals a hypoxiasensitive, endothelial-centered pathway activated in ischemic heart failure. Am J Physiol Heart
Circ Physiol. 2008;294(1):H8898

7. Atluri P, Morine KJ, Liao GP, Panlilio CM, Berry MF, Hsu VM, Hiesinger W, Cohen JE, Joseph Woo Y. Ischemic heart failure enhances endogenous myocardial apelin and APJ receptor expression. Cell Mol Biol Lett. 2007; 12(1):127-38.

8. Berry MF, Pirolli TJ, Jayasankar V, Burdick J, Morine KJ, Gardner TJ, Woo YJ. Apelin has in vivo inotropic effects on normal and failing hearts. Circulation. 2004; 110 (11 Suppl 1): II187-93.

9. Kleinz MJ, Davenport AP. Emerging roles of apelin in biology and medicine. Pharmacol Ther. 2005; 107(2):198-211.

10. Zhong JC, Huang DY, Liu GF, Jin HY, Yang YM, Li YF, Song XH, Du K. Effects of all-trans retinoic acid on orphan receptor APJ signaling in spontaneously hypertensive rats. Cardiovasc Res. 2005;65(3):743-50.

11. Csont T, Balogh $G$, Csonka $C$, Boros I, Horváth I, Vigh L, Ferdinandy P. Hyperlipidemia induced by high cholesterol diet inhibits heat shock response in rat hearts. Biochem Biophys Res Commun. 2002 Feb 8; 290(5): 1535-8.

12. Butler DG, Butt DA. Physiological doses of [Ile5]- and [Val5]-Angiotensin II fail to increase plasma catecholamines at the peak pressor response in rats. Arch Int Pharmacodyn Ther. 1995 Mar-Apr; 329(2):272-82.

13. De Gennaro Colonna $V$, Rigamonti A, Fioretti $S$, 
Bonomo S, Manfredi B, Ferrario P, Bianchi M, Berti F, Muller EE, Rossoni G. Angiotensin-converting enzyme inhibition and angiotensin AT1receptor antagonism equally improve endothelial vasodilator function in L-NAME-induced hypertensive rats. Eur J Pharmacol. 2005 Jun 15; 516(3):253-9.

14. Tatemoto K, Takayama K, Zou MX, Kumaki I, Zhang W, Kumano K, Fujimiya M. The novel peptide apelin lowers blood pressure via a nitric oxidedependent mechanism. Regul Pept. 2001 Jun 15;99(2-3):87-92.

15. Allain CC, Poon LS, Chan CS, Richmond W, Fu PC. Enzymatic determination of total serum cholesterol. Clin Chem. 1974; 20(4):470-5

16. Fruchart JC. Separation of low density lipoproteins. Rev Fr Des Laboratories, 1982, 103: 7-17.

17. Burstein,M.;Scholnick,H.R and Morfin, R .Separation of highdensity lipoproteins .J.Lipid.Res. 19:583

18. Fossati P, Prencipe L. Serum triglycerides determined colorimetrically with an enzyme that produces hydrogen peroxide. Clin Chem. 1982 Oct; 28 (10):2077-80.

19. Bartholomew P. A rapid method for assay of nitrate in urine using the nitrate reductase enzyme of Escherichia Coli. Fd. Chem. Toxic., 1984, 22: 541.

20. Kushner I, Somerville JA. Estimation of the molecular size of C-reactive protein and CXreactive protein in serum.
Biochim Biophys Acta. 1970 Apr 28;207(1):105-14.

21. Liu X, Qu D, He F, Lu Q, Wang J, Cai D. Effect of lycopene on the vascular endothelial function and expression of inflammatory agents in hyperhomocysteinemic rats. Asia Pac J Clin Nutr. 2007; 16 Suppl 1:244-8.

22. Fujiwara Y, Shiraya S, Miyake T, Yamakawa S, Aoki M, Makino H, Nishimura $M$, Morishita R. Inhibition of experimental abdominal aortic aneurysm in a rat model by the angiotensin receptor blocker valsartan. Int J Mol Med. 2008 Dec; 22(6):703-8.

23. Kanome $T$, Watanabe $T$, Nishio $\mathrm{K}$, Takahashi $\mathrm{K}$, Hongo $\mathrm{S}$, Miyazaki A. Angiotensin II upregulates acyl-CoA:cholesterol acyltransferase-1 via the angiotensin II Type 1 receptor in human monocyte-macrophages. Hypertens Res. 2008 Sep;31(9):1801-10.

24. Strawn WB. Pathophysiological and clinical implications of AT(1) and $\mathrm{AT}(2)$ angiotensin II receptors in metabolic disorders: hypercholesterolaemia and diabetes. Drugs. 2002; 62 Spec No 1:31-41.

25. Schulman IH, Zhou MS, Raij L. Interaction between nitric oxide and angiotensin II in the endothelium: role in atherosclerosis and hypertension. J Hypertens Suppl. 2006 Mar;24(1):S45-50.

26. Guo RW, Yang LX, Wang H, Liu B, Wang L. Angiotensin II induces matrix metalloproteinase9 expression via a nuclear factor- 
kappaB-dependent pathway in vascular smooth muscle cells. Regul Pept. 2008 Apr 10; 147(13):37-44.

27. Bolton CH, Downs LG, Victory JG, Dwight JF, Tomson CR, Mackness MI, Pinkney JH. Endothelial dysfunction in chronic renal failure: roles of lipoprotein oxidation and proinflammatory cytokines. Nephrol Dial Transplant. 2001; 16 (6):1189-97.

28. Pueyo ME, Gonzalez W, Nicoletti A, Savoie F, Arnal JF, Michel JB. Angiotensin II stimulates endothelial vascular cell adhesion molecule-1 via nuclear factor-kappaB activation induced by intracellular oxidative stress. Arterioscler Thromb Vasc Biol. 2000; 20(3):645-51.

29. Mehta PK, Griendling KK. Angiotensin II cell signaling: physiological and pathological effects in the cardiovascular system. Am J Physiol Cell Physiol. 2007; 292(1):C82-97.

30. Dandona P, Dhindsa S, Ghanim H, Chaudhuri A. Angiotensin II and inflammation: the effect of angiotensin-converting enzyme inhibition and angiotensin II receptor blockade. J Hum Hypertens. 2007; 21(1):20-7.

31. Peng N, Liu JT, Gao DF, Lin R, Li R. Angiotensin II-induced Creactive protein generation: inflammatory role of vascular smooth muscle cells in atherosclerosis. Atherosclerosis. 2007; 193 (2):292-8.

32. Luchtefeld $\mathbf{M}$, Bandlow $\mathbf{N}$, Tietge UJ, Grote K, Pfeilschifter J, Kaszkin M,
Beck S, Drexler H, Schieffer B. Angiotensin II type 1-receptor antagonism prevents type IIA secretory phospholipase A2dependent lipid peroxidation. Atherosclerosis. 2007; 194 (1): 62-70.

33. Tasci I,Dogru T, NaharciI, Erdem G, Yilmaz MI, Bingol N, Bingol S, Erikci S.. Plasma apelin islower in patients with elevated LDL-cholesterol. Exp Clin Endocrinol Diabetes.2007 Jul;115(7):428-32

34. Gavazzi G, Deffert C, Trocme C, Schäppi M, Herrmann FR, Krause KH. NOX1 deficiency protects from aortic dissection in response to angiotensinIIangiotensin type 1 receptor system.J Mol Cell Cardiol.2006 Nov; 41(5):798-806

35. Iwanaga $Y$, Kihara $Y$, Takenaka H, Kita T. Downregulation of cardiac apelin system in hypertrophied and failing hearts: Possible role of angiotensin II-angiotensin type 1 receptor system. J Mol Cell Cardiol. 2006 Nov; 41(5): 798806.

36. Jiu-Chang Zhong, Xi-Yong Yu, Yu Huang, Lai-Ming Yung, Chi-Wai Lau, Shu-Guang Lin. Apelin modulate aortic vascular tone via endothelial nitric oxide synthase phosphorylation pathway in diabetic in mice Cardiovascular Research 74 (2007); 388-395

37. Zhong JC, Yu XY, Huang Y, Yung LM, Lau CW, Lin SG. Apelin modulates aortic vascular tone via endothelial nitric oxide synthase phosphorylation 
pathway in diabetic mice. Cardiovasc Res. 2007; 74(3):38895.

38. Katugampola SD, Kuc RE, Maguire JJ, Davenport AP. Gprotein-coupled receptors in human atherosclerosis: comparison of vasoconstrictors (endothelin and thromboxane) with recently de-orphanized (urotensin-II, apelin and ghrelin) receptors. Clin Sci (Lond). 2002;103 Suppl 48:171S-175S.

39. Ashley EA, Powers J, Chen M, Kundu R, Finsterbach T, Caffarelli A, Deng A, Eichhorn J, Mahajan R, Agrawal R, Greve J, Robbins R, Patterson AJ, Bernstein D, Quertermous T. The endogenous peptide apelin potently improves cardiac contractility and reduces cardiac loading in vivo. Cardiovasc Res. 2005 Jan 1; 65(1):73-82.

40. Hus-Citharel A, Bouby $\mathbf{N}$, Frugière A, Bodineau L, Gasc JM, Llorens-Cortes C. Effect of apelin on glomerular hemodynamic function in the rat kidney. Kidney Int. 2008 Aug; 74(4):486-94.

41. Erdem G, Dogru T, Tasci I, Sonmez A, Tapan S. Low plasma apelin levels in newly diagnosed type 2 diabetes mellitus. Exp Clin Endocrinol Diabetes. 2008;116(5):289-92.

42. Han S, Wang G, Qi $X$, Englander EW, Greeley GH Jr. Involvement of a Stat3 binding site in inflammation-induced enteric apelin expression. Am J Physiol Gastrointest Liver Physiol. 2008; 295(5):G1068-78.

43. Ishida $J$, Hashimoto $T$, Hashimoto Y, Nishiwaki S, Iguchi T, Harada S, Sugaya T, Matsuzaki H, Yamamoto R, Shiota N, Okunishi H, Kihara M, Umemura S, Sugiyama F, Yagami K, Kasuya Y, Mochizuki N, Fukamizu A. Regulatory roles for APJ, a seven-transmembrane receptor related to angiotensin-type 1 receptor in blood pressure in vivo. J Biol Chem. 2004; 279 (25):26274-9. 


\section{دراسة عن تأثير الابلين أو مثبطات مستقبلات انجيوتنسين- على نموذج لتصلب الشر ايين}

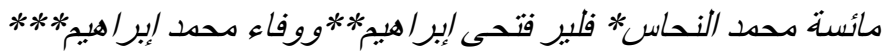

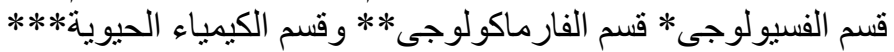

$$
\begin{aligned}
& \text { كلية الطب - جامعة طنطا }
\end{aligned}
$$

كان الهدف من هذا البحث هو التحقق من تأثير الابلين (واحد من الاديبوكينز) أو اللوزرتان

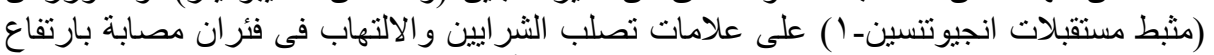

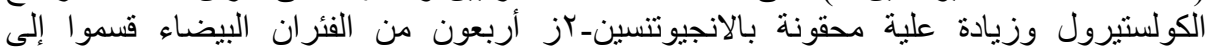

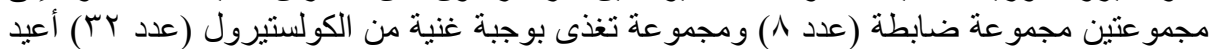

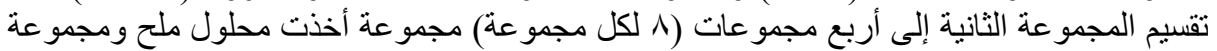

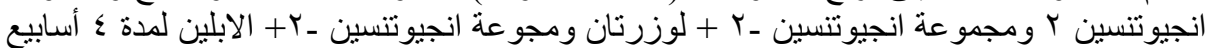

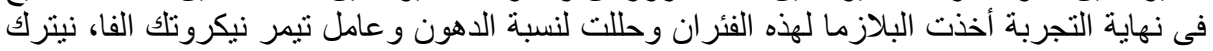

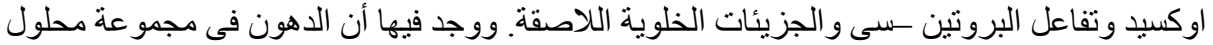

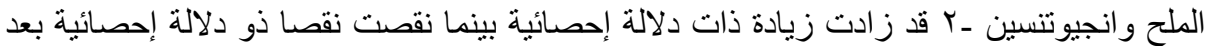

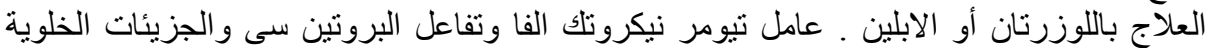

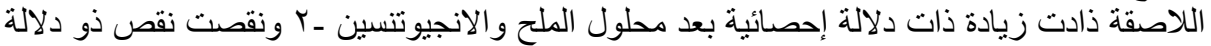

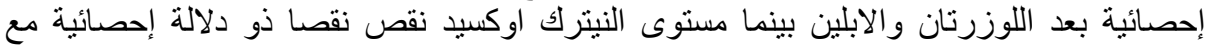

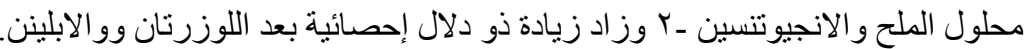

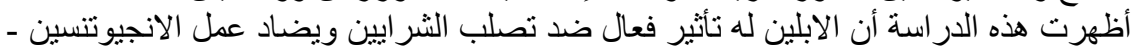

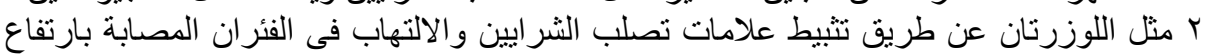

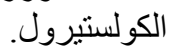

